\title{
Hubungan Pengetahuan dan Sikap Tenaga Kesehatan dengan Perilaku pemberian Teknik Relaksasi dan Teknik Distraksi pada Nyeri Pasien Pasca Operasi Sectio Caesarea di Rumah Sakit Baiturrahim
}

\author{
Yuliana $^{1}$, Nikmatur Rohma ${ }^{2}$ \\ ${ }^{1,2}$ Program Studi SI Keperawatan Sekolah Tinggi Ilmu kesehatan Baiturrahim Jambi \\ Email:nsyuliana2885@gmail.com
}

Submitted : 20/02/2021

Accepted: 10/09/2021

Published: 15/09/2021

\begin{abstract}
Sectio caesaria surgery can cause changes in the continuity of body tissues and the aftereffect of delivery of a caesarean section is that the patient will feel pain after 2 hours of operation to 3 days and the pain feels hot in the incision scar. Efforts to reduce pain intensity are using nonpharmacological pain management, namely distraction and relaxation techniques. This study used cross sectional approach by using description correlation design which conducted at Baiturrahim hospital Jambi city, sample were health personnel (Nurse and Midwife), the sampling technique used total sampling. The collecting of data used a questionnaire by using Chi-Square test. The findings indicated that from 21 respondents 13 (61.9\%) respondents have sufficient knowledge of health personnel, 14 (71.4\%) respondents have Positive attitude of health personnel, 20 (95.2\%) respondents have good health personnel behavior in giving distraction and relaxation techniques to pain patients. From the result of chi square test indicated that score p-value 0.381 so that the null hypothesis is accepted, namely there is no correlation between knowledge of health personnel with the behavior of giving distraction and relaxation techniques in postoperative pain patients with sectio caesarea at Baiturrahim hospital. It is expected to Baiturrahim hospital in order to increase services in providing non-pharmacological techniques to reduce pain intensity in postcaesarean section patients.
\end{abstract}

Keywords : distraction, health personnel, relaxation, sectio caesarea

\begin{abstract}
Abstrak
Tindakan operasi sectio caesaria dapat menyebabkan terjadinya perubahan kontinuitas jaringan tubuh dan akibat lanjut dari persalinan sectio caesaria adalah pasien akan merasakan nyeri setelah 2 jam operasi sampai 3 hari dan nyeri terasa panas di bagian bekas luka insisi. Upaya untuk melakukan penurunan intensitas nyeri adalah menggunakan manajemen nyeri nonfarmakologi yaitu teknik distraksi dan teknik relaksasi. Penelitian ini menggunakan metode pendekatan cross sectional dengan desain penelitian deskripsi korelasi yang dilaksanakan di Rumah Sakit Baiturrahim Kota Jambi, sampel yang digunakan adalah tenaga kesehatan (perawat dan bidan), teknik sampling yang digunakan adalah total sampling. Instrumen pengumpulan data adalah kuesioner dan menggunakan uji statistik Chi-Square. Hasil penelitian menunjukkan dari 21 responden $13(61,9 \%)$ responden memiliki pengetahuan tenaga kesehatan yang cukup, $14(71,4 \%)$ responden memiliki Sikap tenaga kesehatan yang positif, $20(95,2 \%)$ responden memiliki perilaku tenaga kesehatan yang baik dalam pemberian teknik distraksi dan teknik relaksasi pada pasien nyeri. Hasil uji statistik Chi Square menunjukkan nilai $p$-value 0,381 sehingga hipotesis nol diterima yaitu Tidak ada hubungan antara pengetahuan tenaga kesehatan dengan perilaku pemberian teknik distraksi dan teknik relaksasi pada pasien nyeri pasca operasi sectio caesarea di Rumah Sakit Baiturrahim. Diharapkan kepada rumah sakit baiturrahim agar dapat meningkatkan pelayanan dalam pemberian teknik nonfarmakologi untuk menurunkan intensitas nyeri pada pasien pasca operasi sectio caesarea.
\end{abstract}

Kata kunci : distraksi, relaksasi, sectio caesarea, tenaga kesehatan 


\section{PENDAHULUAN}

Sectio Caesarea adalah sebuah metode melahirkan anak dengan melakukan sebuah irisan pembedahan yang menembus abdomen seorang ibu (laparatomi) dan uterus (histerektomi) untuk mengeluarkan satu bayi atau lebih. Operasi sectio caesarea dilakukan jika kelahiran pervaginal mungkin akan menyebabkan resiko pada ibu ataupun pada janin, serta untuk mempertahankan kehidupan atau kesehatan ibu dan janinnya (Maryunani, 2014). Sectio Caesarea elektif adalah Sectio Caesarea yang dilakukan atas indikasi obsetri, medis atau dilakukan karena keinginan pasien. Sectio Caesarea elektif biasanya juga disebut Sectio Caesarea terencana dan dilaksanakan sebelum terjadinya persalinan. Hal yang sebaliknya adalah apabila Sectio Caesarea terpaksa dilakukan pada masa persalinan, tindakan pada keadaan ini disebut sebagai Sectio Caesarea emergensi. (Krisnadi, Anwar, dan Alamsyah, 2012).

Menurut World Health Organization (WHO) pada tahun 2014, yang dikutip oleh Bijalmiah (2018), bahwa Sectio Caesarea(SC) terus meningkat di seluruh dunia, khususnya di negara-negara yang berpenghasilan menengah dan tinggi diantaranya adalah Australia (32\%), Brazil (54\%), dan Colombia (43\%). Angka kejadian Sectio Caesareadi Indonesia pada tahun 2005 sampai dengan tahun 2011 rata-rata sebesar $7 \%$ dari jumlah semua kelahiran, sedangkan pada tahun 2006 sampai dengan tahun 2012 rata-rata kejadian Sectio Caesarea meningkat menjadi sebesar 12\% (WHO, 2013 dan 2014).

Tipe pembedahan sectio caesarea dapat dibedakan berdasarkan tipe insisi bedah. Penentuan tipe insisi bedah tergantung pada presentasi janin dan kecepatan prosedur yang akan dilakukan. Tipe insisi bedah tersebut diantaranya adalah insisi pada segmen bawah rahim dan insisi segmen atas rahim (Sjamsuhidajat, 2005 dalam Irmawaty, 2013). Tindakan operasi menyebabkan terjadinya perubahan kontinuitas jaringan tubuh. Pada proses operasi digunakan anastesi agar pasien tidak merasakan nyeri, namun setelah operasi selesai dan pasien mulai sadar akan merasakan nyeri pada bagian tubuh yang mengalami pembedahan. Nyeri yang dirasakan ibu post sectio caesarea berasal dari luka yang terdapat dari perut (Sjamsuhidajat, 2005 dalam Irmawaty, 2013).

Pasien yang dilakukan sectio caesaria merasakan nyeri setelah 2 jam operasi sampai 3 hari dan nyeri terasa panas di bagian bekas luka insisi (Sukowati, 2010). Menurut penelitian Shintadewi (2011), Nyeri dapat mengganggu pola istirahat, nyeri yang berkepanjangan dapat menyebabkan stress fisik, kecemasan, ketakutan, dan rasa putus asa. Nyeri yang dialami ibu setelah persalinan bisa memperlambat ibu untuk bergerak, mengalami kesulitan melakukan bonding pada bayi, ibu juga akan merasa nyeri saat menggendong dan menyusui bayi. Nyeri dapat diartikan sebagai suatu sensasi yang tidak menyenangkan baik secara sensori maupun emosional yang berhubungan dengan adanya suatu kerusakan jaringan atau faktor lain, sehingga individu merasa tersiksa, menderita yang pada akhirnya akan mengganggu aktivitas sehari-hari, psikis dan lain-lain (Sutanto dan Fitriana, 2017).

Strategi dalam penatalaksanaan nyeri mencakup baik pendekatan farmakologis dan non farmakologis. Tindakan farmakologis dilakukan dalam kolaborasi dengan dokter atau perawat dan pasien. Pemberian analgesia rata-rata dapat disuntik $75 \mathrm{mg}$ Meperidin (intra muskuler) setiap 3 jam sekali, bila diperlukan untuk mengatasi rasa sakit atau dapat disuntikkan dengan cara serupa $10 \mathrm{mg}$ morfin. Obat-obatan antiemetik, misalnya protasin $25 \mathrm{mg}$ biasanya diberikan bersama-sama dengan pemberian preparat narkotik (Jitowiyono dan Kristiyanasari, 2012). Manajemen nyeri non farmakologi termasuk didalamnya adalah intervensi tubuh-pikiran yang 
diantaranya adalah terapi dansa, teknik relaksasi, imajinasi terbimbing, meditasi imeges, teknik distraksi, usaha pemulihan (doa), psikoterapi dan yoga (Syaripudin, 2018).

Berdasarkan penelitian Stania (2012) tentang "pengaruh teknik relaksasi dan teknik distraksi terhadap perubahan intensitas nyeri pada pasien post operasi di ruang irina atas rsup prof. Dr. R. D. Kandou manado" dengan jumlah sampel 25 Responden. Hasil penelitian yang dilakukan terhadap 15 responden didapatkan sebelum dilakukan teknik relaksasi didapatkan sebagian besar responden mengalami intensitas nyeri lebih nyeri yaitu sebanyak 6 orang $(40 \%)$, intensitas nyeri sedikit lebih nyeri sebanyak 4 orang $(26,7 \%)$, intensitas nyeri sangat nyeri 3 orang $(20 \%)$ dan intensitas nyeri sedikit nyeri sebanyak 2 orang (13,3\%). Setelah dilakukan teknik relaksasi, sebanyak 2 responden menyatakan tidak mengalami nyeri dan tidak ada responden yang mengalami intensitas nyeri sangat nyeri dan intensitas nyeri lebih nyeri. Sedangkan hasil Hasil penelitian yang dilakukan terhadap 10 responden didapatkan sebelum dilakukan teknik distraksi dengan intensitas nyeri sedikit lebih nyeri yaitu berjumlah masingmasing 5 orang atau 33,3\%, reponden lain mengalami intensitas sangat nyeri berjumlah 4 orang $(26,7 \%)$ dan nyeri sangat hebat 1 orang $(6,7 \%)$. Setelah diberikan teknik distraksi terdapat 1 orang $(6,7 \%)$ menyatakan tidak nyeri. Setelah dilakukan teknik distraksi tidak terdapat pasien yang mengalami intensitas nyeri sangat nyeri dan nyeri sangat hebat.

Distraksi dapat menurunkan persepsi nyeri dengan menstimulasi system kontrol desenden, yang mengakibatkan lebih sedikit stimuli nyeri yang ditransmisikan ke otak, sedangkan teknik relaksasi dipercaya dapat menurunkan intensitas nyeri dengan merilekskan ketegangan otot yang menunjang nyeri (Nurhayati, 2011).
Pemenuhan kebutuhan kepuasan pasien selama di rumah sakit diperlukan tenaga kesehatan yang harus mempunyai pengetahuan (knowledge), keterampilan (skill) yang tinggi serta mempunyai sikap professional (attitude) dan dapat menunjang pembangunan kesehatan. Pelayanan yang diberikan akan berkualitas dan dapat memberikan kepuasan pada pasien sebagai penerima pelayanan maupun perawat sebagai pemberi pelayanan (Hamid, 2000 dalam Eriawan 2013).

Penatalaksanaan pasca operasi dan pemulihan dari anastesia sangat memerlukan pengetahuan dan keterampilan keperawatan yang profesional. Tingkat pengetahuan perawat dan keterampilan dalam perawatan pasien pasca operasi sangat dibutuhkan untuk mencegah komplikasi yang memperlama perawatan di rumah sakit atau membahayakan diri pasien (Rothrock, 1999). Perawat harus mempunyai pengetahuan dan keterampilan yang memadai dalam semua aspek perawatan pre operatif mencakup fungsi pernapasan yang optimal, meminimalkan nyeri dan ketidaknyamanan pasca operasi (mual dan muntah, distensi abdomen, cegukan), pemeliharaan suhu tubuh normal, bebas dari cidera, pemeliharaan keseimbangan nutrisi, kembalinya fungsi perkemihan yang normal, dan tidak adanya komplikasi (Baradero et al, 2008 dalam Eriawan, 2013).

Menurut Notoatmodjo (2003). Pengetahuan adalah hasil "tahu" dan ini terjadi setelah orang mengadakan penginderaan terhadap suatu objek tertentu. Penginderaan terhadap obyek terjadi melalui panca indera manusia yakni penglihatan, pendengaran, penciuman. Rasa dan raba dengan sendiri. Pada waktu penginderaan sampai menghasilkan pengetahuan tersebut sangat dipengaruhi oleh intensitas perhatian persepsi terhadap obyek. Sebagian besar pengetahuan manusia diperoleh melalui mata dan telinga (Wawan dan Dewi, 2011). 
Eagly dan Chaiken (1993) mengemukakan bahwa sikap dapat diposisikan sebagai hasil evaluasi terhadap objek sikap, yang diekspresikan ke dalam proses-proses kognitif, afektif dan perilaku. Sebagai hasil evaluasi, sikap yang disimpulkan dari berbagai pengamatan terhadap objek diekspresikan dalam bentuk respon kognitif, afektif (emosi), maupun perilaku. Melalui sikap, kita memahami proses kesadaran yang menentukan tindakan nyata dan tindakan yang mungkin dilakukan individu dalam kehidupan sosialnya (Wawan dan Dewi, 2011).

Berdasarkan penelitian Saifullah (2015) tentang "Hubungan tingkat pengetahuan perawat dengan tindakan perawat dalam manajemen nyeri pasien post operasi di Bangsal Bedah RSUD dr Soehadi Prijonegoro Sragen" dengan jumlah sampel 36 responden. Hasil penelitian didapatkan sebagian besar perawat mempunyai tingkat pengetahuan baik yaitu sebanyak 20 responden $(56 \%)$ dan sebagian besar mempunyai tindakan manajemen nyeri yang baik yaitu 19 responden $(53 \%)$.

Berdasarkan hasil wawancara dengan kepala ruangan di ruang operasi (OK), pada tanggal 23 Maret 2020, anastesi yang digunakan diruang OK Rumah Sakit Baiturrahim Kota Jambi adalah anastesi spinal, jika pasien dalam keadaan kegawatdaruratan pasien diberikan anastesi umum (GA). Pengaruh anastesi spinal akan hilang \pm 4 jam dan pasien akan mulai merasakan nyeri. Pada anastesi umum (GA) pengaruh anastesi hilang setelah pasien sadar, dan saat itu pasien akan merasakan nyeri. Setelah pengaruh anastesi hilang dan pasien mulai merasakan nyeri biasanya perawat memberikan obat analgesik untuk menurunkan intensitas nyeri sesuai instruksi dokter, analgesik dengan dosis 3x dalam 24 jam atau setiap 8 jam. Teknik nonfarmakologi yang digunakan teknik relaksasi nafas dalam dan teknik distraksi.
Berdasarkan survey awal yang peneliti lakukan di ruang rawat inap Rumah Sakit Baiturrahim Kota Jambi. Peneliti melakukan wawancara kepada 5 orang tenaga kesehatan, didapatkan hasil 3 dari 5 orang perawat mengatakan teknik relaksasi dan teknik distraksi adalah tindakan nonfarmakologi untuk menurunkan nyeri post operasi dan untuk membuat pasien merasa nyaman dan rileks, sedangkan 2 perawat lagi mengatakan teknik relaksasi dan teknik distraksi adalah kegiatan yang dapat meningkatkan ketenangan, menurunkan stress, cemas atau marah. 4 dari 5 orang perawat mengatakan sangat setuju jika pasien diberikan teknik nonfarmakologi untuk menurunkan intensitas nyeri, sedangkan 1 orang perawat mengatakan kurang setuju, lebih baik diberikan obat analgesik saja. 4 dari 5 orang perawat mengatakan membantu mengajarkan teknik relaksasi dan teknik distraksi pada ibu post operasi sectio caesarea, sedangkan 1 orang perawat mengatakan tidak ikut mendampingi untuk melakukan teknik relaksasi dan teknik distraksi sehingga pasien untuk latihan relaksasi dan sistraksi dibantu oleh keluarganya.

Berdasarkan permasalahan yang telah dipaparkan diatas, maka peneliti tertarik melakukan penelitian tentang "Hubungan Pengetahuan dan Sikap tenaga kesehatan dengan Perilaku Pemberian Teknik Relaksasi dan Teknik Distraksi pada Nyeri Pasien Pasca Operasi Sectio Caesarea"

\section{METODE PENELITIAN}

Desain penelitian yang digunakan pada penelitian ini adalah Deskripsi Korelasi dengan metode pendekatan cross sectional. Penelitian ini terdiri dari 2 variabel, variabel independen yaitu pengetahuan dan sikap, variabel dependen yaitu perilaku pemberian teknik distraksi dan teknik relaksasi. Populasi dalam penelitian ini adalah seluruh tenaga kesehatan (perawat dan bidan) yang 
bertugas di ruang rawat inap dan ruang VIP Rumah sakit Baiturrahim Kota Jambi yang berjumlah 28 orang. Sampel dalam penelitian ini berjumlah 21 orang dengan cara Total sampling dengan kriteria inklusi: Tenaga kesehatan perawat dan bidan yang dinas di ruang rawat inap dan ruang VIP Rumah Sakit Baiturrahim, Tenaga kesehatan dengan pendidikan minimal D3 Keperawatan dan D3 Kebidanan, Tenaga kesehatan yang telah memberikan persetujuan untuk dijadikan sampel, kriteria eklusi : Kepala ruangan rawat inap dan ruang VIP. Instrumen yang digunakan untuk mengukur pengetahuan, sikap dan perilaku tenaga kesehatan adalah kuesioner. Sebelum melakukan penelitian kuesioner terlebih dilakukan uji validitas pada 10 responden di Rumah Sakit H. Abdul Manap Kota Jambi. Analisis yang digunakan dalam penelitian ini adalah analisis Chi-Square

HASIL DAN PEMBAHASAN

Tabel 1. Karakteristik Responden Tenaga Kesehatan di Rumah Sakit Baiturrahim

\begin{tabular}{ccc} 
Umur & $\boldsymbol{f}$ & $\boldsymbol{\%}$ \\
\hline $17-25$ tahun & 6 & $28,6 \%$ \\
$26-35$ tahun & 15 & $71,4 \%$ \\
Jenis Kelamin & & \\
Laki - laki & 4 & $19,1 \%$ \\
Perempuan & 17 & $80,9 \%$ \\
Pendidikan & & \\
Diploma III & 7 & $33,3 \%$ \\
Diploma IV & 4 & $19 \%$ \\
Ners & 10 & $47,6 \%$ \\
\hline
\end{tabular}

Berdasarkan Tabel 1 menunjukkan bahwa umur tenaga kesehatan sebagian besar berada dalam kategori dewasa awal yaitu berusia antara 26-35 tahun, 80,9 \% berjenis kelamin perempuan dan $47.6 \%$ memiliki pendidikan akhir profesi (Ners)
Tabel 2. Distribusi frekuensi pengetahuan tenaga kesehatan dalam pemberian teknik distraksi dan teknik relaksasi pada pasien pasca operasi sectio caesarea

\begin{tabular}{ccc}
\hline Pengetahuan & $\boldsymbol{F}$ & $\boldsymbol{\%}$ \\
\hline Baik & 8 & $38,1 \%$ \\
Cukup & 13 & $61,9 \%$ \\
Kurang & 0 & $0 \%$ \\
\hline Jumlah & 21 & 100
\end{tabular}

Berdasarkan Tabel 2 tenaga kesehatan (perawat dan bidan) memiliki pengetahuan cukup lebih banyak daripada responden yang memiliki pengetahuan baik dan kurang.

Tabel 3. Distribusi frekuensi sikap tenaga kesehatan dalam pemberian teknik distraksi dan teknik relaksasi pada pasien pasca operasi sectio caesarea

\begin{tabular}{ccc} 
Sikap & $\boldsymbol{f}$ & $\boldsymbol{\%}$ \\
\hline Positif & 15 & 71,4 \\
Negatif & 6 & 28,6 \\
Jumlah & 21 & 100 \\
\hline
\end{tabular}

Berdasarkan Tabel 3. diatas dapat diketahui bahwa dari 21 responden, menunjukkan sikap tenaga kesehatan (71.4\%) bersikap positif terhadap pemberian teknik relaksasi dan teknik distraksi

Tabel 4. Distribusi frekuensi perilaku tenaga kesehatan dalam pemberian teknik distraksi dan teknik relaksasi pada pasien pasca operasi sectio caesarea

\begin{tabular}{ccc} 
Perilaku & $\boldsymbol{F}$ & $\boldsymbol{\%}$ \\
\hline Baik & 20 & 95,2 \\
Kurang Baik & 1 & 4,8 \\
Jumlah & 21 & 100 \\
\hline
\end{tabular}

Berdasarkan Tabel 4 diketahui bahwa dari 21 responden, sebanyak $20(95,2 \%)$ responden memiliki perilaku baik. 


\section{Analisis Bivariat}

Tabel 5. Hubungan Pengetahuan Tenaga Kesehatan Dengan Perilaku Pemberian Teknik Distraksi dan Teknik Relaksasi Pada Pasien Nyeri Pasca Operasi Sectio Caesarea di Rumah Sakit Baiturrahim

\begin{tabular}{|c|c|c|c|c|c|c|c|}
\hline \multirow{3}{*}{$\begin{array}{c}\text { Pengetahuan } \\
\text { Tenaga Kesehatan }\end{array}$} & \multicolumn{4}{|c|}{$\begin{array}{c}\text { Perilaku Pemberian Teknik } \\
\text { Distraksi dan Teknik Relaksasi }\end{array}$} & \multirow{2}{*}{\multicolumn{2}{|c|}{ Total }} & \multirow{3}{*}{$P$-Value } \\
\hline & \multicolumn{2}{|c|}{ Baik } & \multicolumn{2}{|c|}{ Kurang Baik } & & & \\
\hline & $f$ & $\%$ & $f$ & $\%$ & $f$ & $\%$ & \\
\hline Baik & 7 & 33,3 & 1 & 4,8 & 8 & 38,1 & \multirow{3}{*}{0,381} \\
\hline Cukup & 13 & 61,9 & 0 & 0 & 13 & 61,9 & \\
\hline Jumlah & 1 & 4,8 & 20 & 95,2 & 21 & 100 & \\
\hline \multirow{2}{*}{\multicolumn{8}{|c|}{ 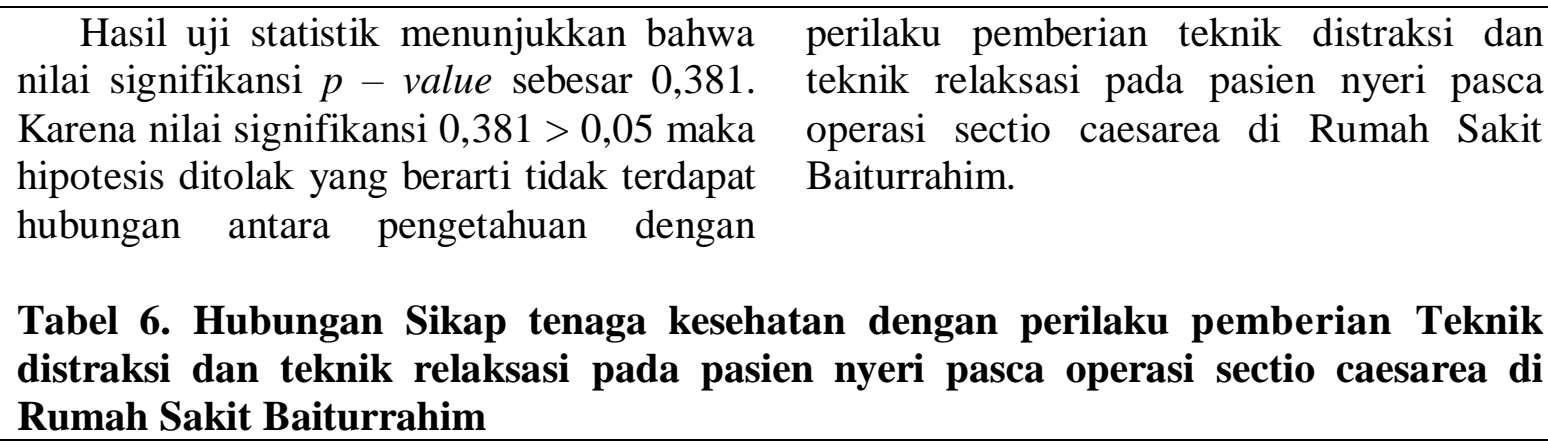 }} \\
\hline & & & & & & & \\
\hline \multirow{3}{*}{$\begin{array}{c}\text { Sikap } \\
\text { Tenaga Kesehatan }\end{array}$} & \multicolumn{4}{|c|}{$\begin{array}{c}\text { Perilaku Pemberian Teknik } \\
\text { Distraksi dan Teknik Relaksasi }\end{array}$} & \multirow{2}{*}{\multicolumn{2}{|c|}{ Total }} & \multirow{3}{*}{$P$ - Value } \\
\hline & \multicolumn{2}{|c|}{ Kurang Baik } & \multicolumn{2}{|c|}{ Baik } & & & \\
\hline & $f$ & $\%$ & $f$ & $\%$ & $f$ & $\%$ & \\
\hline Positif & 1 & 4,8 & 14 & 61,9 & 15 & 66,6 & \multirow{3}{*}{0,714} \\
\hline Negatif & 0 & 0 & 6 & 28,6 & 6 & 33,4 & \\
\hline Jumlah & 1 & 4,8 & 20 & 95,2 & 21 & 100 & \\
\hline
\end{tabular}

Hasil uji statistik diperoleh nilai signifikansi $p$ - value sebesar 0,714 . Karena nilai signifikansi $0,714>0,05$ maka hipotesis ditolak yang berarti tidak terdapat hubungan antara sikap dengan perilaku tenaga kesehatan dalam pemberian teknik distraksi dan teknik relaksasi pada pasien nyeri pasca operasi sectio caesarea di Rumah Sakit Baiturrahim.
Hubungan pengetahuan tenaga kesehatan dengan perilaku pemberian Teknik distraksi dan teknik relaksasi pada nyeri pasien pasca operasi sectio caesarea

Menurut Priyoto (2016) pengetahuan merupakan penginderaan terhadap objek tertentu, pengindraan terjadi melalui panca indra manusia yakni indra penglihatan, pendengaran, penciuman, rasa dan raba. Sebagian besar pengetahuan manusia diperoleh melalui mata dan telinga yaitu proses melihat dan mendengar. Selain itu 
proses pengalaman dan proses belajar dalam pendidikan formal maupun informal. Berdasarkan hasil penelitian didapatkan bahwa mayoritas responden berpengetahuan cukup sebanyak 13 orang $(61,9 \%)$ dan memiliki perilaku yang baik sebanyak 7 orang $(33,3 \%)$.

Pengetahuan atau kognitif merupakan domain yang sangat penting dalam membentuk tindakan seseorang (over behavior) dari pengalaman dan penelitian, perilaku yang didasarkan oleh pengetahuan akan lebih melekat daripada perilaku yang tidak didasari oleh pengetahuan. diketahui bahwa dari $8(38,1 \%)$ responden yang memiliki pengetahuan yang baik terdapat 7 $(33,3 \%)$ responden memiliki perilaku yang baik dalam pemberikan teknik distraksi dan teknik relaksasi dan sebanyak $1 \quad(4,8 \%)$ responden memiliki perilaku yang kurang baik dalam pemberikan teknik distraksi dan teknik relaksasi. sebanyak $13 \quad(61,9 \%)$ responden yang memiliki pengetahuan cukup, keseluruhan memiliki perilaku yang baik dalam pemberian teknik distraksi dan teknik relaksasi.

Hal ini disebabkan karena pengetahuan dapat menjadikan seseorang memiliki kesadaran sehingga seseorang akan berperilaku sesuai pengetahuan yang dimiliki. Perubahan perilaku yang dilandasi pengetahuan, kesadaran dan sikap yang positif brsifat langgeng karena didasari oleh kesadaran mereka sendiri bukan paksaan (Notoatmodjo, 2011).

Hasil uji statistik menunjukkan bahwa nilai signifikansi $p$-value sebesar 0,381 . Karena nilai signifikansi 0,381 >0,05 maka hipotesis ditolak yang berarti tidak terdapat hubungan antara pengetahuan dengan perilaku pemberian teknik distraksi dan teknik relaksasi pada pasien nyeri pasca operasi sectio caesarea di Rumah Sakit Baiturrahim.

Hasil penelitian ini tidak sejalan dengan hasil penelitian Mudiah (2013) yang menyatakan bahwa Hasil uji statistik menggunakan uji Chi-Square (X2) dapat diambil kesimpulan bahwa ada hubungan yang signifikan antara pengetahuan perawat dengan pelaksanaan manajemen nyeri nonfarmakologi pada pasien pasca operasi di ruang Cempaka RSUD Abdul Wahab Sjahranie Samarinda, karena nilai signifikan $(\rho)=0,024$ dimana nilai ini lebih kecil dari nilai yang dipakai yaitu $\alpha=0,05$ sehingga Ho ditolak atau ada hubungan yang bermakna antara variabel independen dengan variabel dependen

Selain pendidikan dan pengalaman bekerja, faktor lingkungan juga mempengaruhi tingkat pengetahuan seseorang. Faktor lingkungan yang merupakan seluruh kondisi yang ada disekitar manusia dan pengaruhnya yang dapat mempengaruhi perkembangan dan perilaku orang atau kelompok (Maulana, 2003 dalam Mudiah, 2013). Faktor lingkungan akan membuat tenaga kesehatan dapat saling menukar pengalaman, keterampilan, maupun ilmu pengetahuan dalam pemberian teknik distraksi dan teknik relaksasi. Lingkungan yang mendukung akan membuat seseorang memiliki pengetahuan yang baik.

\section{Hubungan sikap tenaga kesehatan dengan perilaku pemberian Teknik distraksi dan teknik relaksasi pada nyeri pasien pasca operasi sectio caesarea di Rumah Sakit Baiturrahim.}

Sikap merupakan reaksi atau proses seseorang yang masih tertutup terhadap stimulus atau objek. Sikap tidak dapat dilihat langsung tetapi hanya dapat ditafsirkan terlebih dahulu dari perilaku yang tertutup. Hal ini menunjukkan bahwa sikap tertutup hanya terlihat apabila adanya suatu tindakan yang diperlihatkan seseorang. Tindakan yang diperlihatkan tersebut menunjukkan suatu perilaku dari seseorang, sehingga dengan demikian apabila seseorang menyikapi sesuatu dengan positif, maka akan menghasilkan suatu perilaku yang baik dan sebaliknya apabila seseorang menyikapinya dengan 
negatif, maka akan menghasilkan perilaku yang kurang baik

Berdasarkan Tabel 2.1 diatas dapat diketahui bahwa dari $15(66,6)$ responden yang memiliki sikap yang positif terdapat $14(61,9)$ responden memiliki perilaku yang baik dalam pemberian teknik distraksi dan teknik relaksasi dan sebanyak $1 \quad(4,8)$ responden memiliki perilaku yang kurang baik dalam pemberian teknik distraksi dan teknik relaksasi, sebanyak $6 \quad(28,6)$ responden memiliki sikap negatif, tidak terdapat responden yang memiliki perilaku yang kurang baik dalam pemberian teknik distraksi dan teknik relaksasi.

Menurut Wawan dan Dewi (2011) sikap terdiri dari sikap positif dimana memiliki kecenderungan tindakan seperti mendekati, menyenangi, mengharapkan obyek tertentu dan sikap negatif terdapat kecenderungan untuk menjauhi, menghindari, membenci, tidak menyukai obyek tertentu. Eagly dan Chaiken (1993), mengemukakan bahwa sikap dapat diposisikan sebagai hasil evaluasi terhadap objek sikap, yang diekspresikan ke dalam proses-proses kognitif, afektif dan perilaku. Sebagai hasil evaluasi, sikap yang disimpulkan dari berbagai pengamatan terhadap objek diekspresikan dalam bentuk respon kognitif, afektif (emosi), maupun perilaku. Melalui sikap, kita memahami proses kesadaran yang menentukan tindakan nyata dan tindakan yang mungkin dilakukan individu dalam kehidupan sosialnya (Wawan dan Dewi, 2011).

Hal ini dapat dibuktikan melalui data yang diperoleh melalui kuesioner bahwa mayoritas responden memiliki sikap yang positif, responden merespon dari stimulus yang diterima tentang pemberian teknik distraksi dan teknik relaksasi melalui tindakannya (perilaku) sebagai tenaga kesehatan. Hal ini dapat dipahami karena tingkat pendidikan responden yang sebagian besar mempunyai latar belakang pendidikan profesi ners yaitu sebanyak 10 (47,6\%), pendidikan D3 sebanyak 7
$(33,3 \%)$ dan pendidikan DIV sebanyak 4 (19\%), dimana semakin tinggi tingkat pendidikan seseorang maka semakin baik pula tingkat pengetahuaanya dan menimbulkan sikap yang positif terhadap pemberian teknik distraksi dan teknik relaksasi.

Hasil uji statistik diperoleh nilai signifikansi $p$ - value sebesar 0,714. Karena nilai signifikansi $0,714>0,05$ maka hipotesis ditolak yang berarti tidak terdapat hubungan antara sikap dengan perilaku tenaga kesehatan dalam pemberian teknik distraksi dan teknik relaksasi pada pasien nyeri pasca operasi sectio caesarea di Rumah Sakit Baiturrahim.

Hasil penelitian ini tidak sejalan dengan penelitian yang dilakukan oleh Dewi (2018) yang menyatakan bahwa perawat yang memiliki sikap positif sebanyak 28 perawat dimana 67,9 \% atau 19 perawat memiliki sikap positif. Hasil analisa hubungan menunjukan bahwa terdapat hubungan antara sikap perawat dengan pelaksanaan manajemen nyeri dengan nilai $\mathrm{p}=0,003$. Perawat yang memiliki pengalaman kurang sebanyak 25 orang, ternyata $68 \%$ atau 17 perawat pelaksanaan manajemen nyeri termasuk kurang. Hasil analisa hubungan menunjukan bahwa terdapat hubungan antara pengalaman dengan manajemen nyeri pasca operasi dengan nilai $\mathrm{p}=0,025$.

Ada faktor lain yang bisa mempengaruhi seseorang berperilaku dengan baik yaitu faktor orang lain yang dianggap penting seperti perilaku caring bisa mempengaruhi tenaga kesehatan yang bersikap positif dapat berperilaku dengan baik yaitu dengan adanya rasa sensitif dalam diri tenaga kesehatan, membuat tenaga kesehatan lebih ikhlas, lebih peka terhadap orang lain. Tenaga kesehatan harus paham tentang asuhan keperawatan management nyeri menggunakan teknik relaksasi dan teknik distraksi untuk menurunkan intensitas nyeri pasien pasca operasi sectio caesarea. 


\section{SIMPULAN}

Tidak Ada Hubungan pengetahuan tenaga kesehatan dengan perilaku pemberian Teknik relaksasi dan teknik distraksi pada nyeri pasien pasca operasi sectio caesarea di Rumah Sakit Baiturrahim. Tidak Ada Hubungan sikap tenaga kesehatan dengan perilaku pemberian Teknik relaksasi dan teknik distraksi pada nyeri pasien pasca operasi sectio caesarea di Rumah Sakit Baiturrahim.

\section{SARAN}

pada pihak tenaga kesehatan dirumah sakit untuk melakukan tindakan asuhan keperawatan management nyeri menggunakan tehnik ralaksasi dan distraksi

\section{UCAPAN TERIMA KASIH}

Terima kasih kepada petugas kesehatan Rumah sakit baiturrahim yang telah membantu proses penelitian ini.

\section{DAFTAR PUSTAKA}

Amin Huda. Aplikasi asuhan keperawatan berdasarkan diagnose medis dan NANDA NIC-NOC. Jakarta: Mediaction; 2015

Asmadi. Teknik prosedur keperawatan konsep dan dasar aplikasi kebutuhan dasar klien. Jakarta: Salemba medica; 2008

Aleef MCM, Labib A. Early mobilitation and ICU rehabilitation of ECMO patients. Qatar medical jurnal. 2017; Art 71

Arisanty IP. Konsep dasar manajemen perawatan. Jakarta: EGC; 2106

Arifin Dahlia. Pengaruh mobilisasi dini terhadap lama hari rawat pasien postoperasi di RSU Haji Makasar. Skripsi. 2010

Brunner and Suddarth. Buku ajar keperawatan medical bedah. Jakarta: EGC; 2002

Conceicao TMA, Gonzales AI, Figueiredo FCXS, Vieira DSR, Bundchen DC.
Safety criteria to strat early mobilization in intensive care units. Systematic review. Rev bras ter intensiva. 2017; 29 (4); 509-519

Ditya W, Zahari A, Afriwadi. Hubungan mobilisasi dini dengan proses penyembuhan luka pada pasien pasca laparatomi di bangsal bedah pria dan wanita RSUP Dr. M. Djamil Padang. Jurnal kesehatan Andalas. 2016; 5(3); 724-729

Dwiyantini M, Puspitaningrum I, Herlina, Wiguna RI, Ningsih HEW. Penelitian quasi-eksperiment dalam keperawatan. Semarang: UNDIP PRESS; 2018

Grace PA. At a glaceilmubedah, edisi 3. Jakarta: Erlangga; 2007

Handayani Halidai. Efek mobilisasi progressife terhadap perubahan derajat rentang gerak sendi dan kadar asam laktat pada pasien dengan ventilasi mekanik di unit perawatan intensif (ICU). Tesis; 2017

Hidayat AA. Kebutuhan dasar manusia. Jakarta: Salemba Medica; 2006

Haswita, Sulistyowati R. Kebutuhan dasar manusia untuk mahasiswa keperawatan dan kebidanan. Jakarta: Trans Info Media; 2017

Julia DK, Peter SD. Keperawatan ortopedik dan trauma. Jakarta: EGC; 2011

Kusumayanti, Devi NLP, Dian NM, Astriani LPN. Faktor-faktor yang mempengaruhi terhadap lamanya perawatan pada pasien pascaoperasi laparatomi di instalasi rawat inap BRSU Tabanan. JAP. 2014; 2(3); 186-193

Majid Abdul. Keperawatan perioperatif. Yogyakarta: Goysen publishing; 2011

Ningrum TP, Isabela C. Gambaran karakteristik pasien wound dehiscence menurut variabel Rotterdam di RSUD kota Bandung. 
Jurnal ilmu keperawatan. 2016; IV (2): 111-115.

Netty Indarmein. Hubungan mobilisasi dini dengan penyembuhan luka postoperasi seksiosesarea di ruang rawat gabung kebidanan RSUD $\mathrm{H}$. Abdul Manap kota Jambi tahun 2012. Jurnal penelitian universitas Jambi serie sains. 2013; 15(1); 5970

Nursalam. Metodologi penelitian ilmu keperawatan, edisi 3. Jakarta: Salemba Medica; 2014

Mubarak WI, Indrawati L, Susanto J. Buku ajar ilmu keperawatan dasar. Jakarta: Salemba medica; 2015

Padila. Buku ajar keperawatan medical bedah. Yogyakarta: Nuha medica; 2012

Potter and Perry. Buku ajar fundamental keperawatan, edisi 4. Jakarta: EGC; 2006

Rahma N, Kasim J, Anggriani S. Hubungan mobilisasi dini terhadap kesembuhan luka pada pasien section caesarea di RSKD ibu dan anak Siti Fatimah Makasar. Jurnal ilmiah kesehatan. 2015; 5(6); 655660

Sandy FPT, Yulinar R, Utami NW. Infeksi luka operasi pada pasien postoperasi laparatomi. Jurnal keperawatan terapan .2015; (1); 14-24

Sjamsuhidajat, Wimde J. Buku ajar ilmu bedah, edisi 3, volume 1. Jakarta: EGC; 2014

Sumarah, Marianingsih E, Kusnanto H, Haryanti W. Pengaruh mobilisasi dini terhadap penyembuhan luka post section caesarea. Jurnal involsi kebidanan. 2013; 3(5); 58-69
Sumartinah, Kusyati E, kustriyanti D, Rahayu H. Hubungan mobilisasi dini dan kadar hemoglobin terhadap penyembuhan luka operasi section caesarea di Semarang. Prosiding konferensi nasional II PPNI Jawa Tengah.2014; 2(1); 237-241

Susantika IY. Mobilisasi dini terhadap penyembuhan luka paska seksio sesaria di RSU.Wahidin Sudiro Husodokota Mojokerto. Jurnal.2015;2(1); 1-7

Simangungso R, Rottie J, Hutauruk M. Hubungan mobilisasi dini dengan proses penyembuhan luka post section caesarea di RSU GMIM Pancaran kasih Manado. E-journal keperawatan. 2018; 6(1);1-6

Supardi S, Rustika. Metodelogi riset keperawatan. Jakarta; Trans Info Media; 2013

Theddeus OH, Prasetyono. Panduan klinis manajemen luka. Jakarta: EGC;2016

Yuwono. Pengaruh beberapa faktor resiko terhadap kejadian surgical site infection (SSI) pada pasien laparatomi emergensi. JMJ; 1(1); 16-25 